"SOCIALIZATION \& HUMAN DEVELOPMENT" INTERNATIONAL JOURNAL

\title{
FEATURES OF BEHAVIOR OF ADOLESCENTS FROM FAMILIES WITH DIFFERENT TYPES OF UPBRINGING AND PARENTHOOD
}

https://doi.org/10.37096/SHDISJ-20-1.1-0005

Onyshchenko Vitalii

ORCID: 0000-0002-4373-5256

\begin{abstract}
Absract
The aim of this study was to investigate the relationship between the type of family upbringing and adolescent deviant behavior. The study was conducted in 2019 at the Ukrainian Physics and Mathematics Lyceum of Taras Shevchenko National University of Kyiv and was based on a survey of 60 families, namely 60 adolescents aged 14-16 and their parents (60 persons). Standardized questionnaires were used: the Questionnaire to determine the propensity for deviant behavior (O.M. Orel), the Questionnaire of paternity types (V.B. Shapar), the Questionnaire for the analysis of parental family relationships (ASV) (EG Eidemiller, V. Justicis). The main results of theoretical and empirical researches of influence of family on formation of deviant behavior of teenagers are covered in the article. Deviant behavior is the result of restructuring of the body, the transition from childhood to adulthood, which is manifested in all aspects of human development during this period. In this case, deviations in the behavior of adolescents are manifested in the commission of destructive, conflicting, asocial and aggressive actions. Objective factors of increase in the number of adolescents with deviant behavior were clarified: worsening social situation; increasing the number of families living in difficult or unsatisfactory conditions; application of conflict and asocial styles of education, transfer of responsibility for the development of the child to other institutions of socialization. Next deviations in adolescent behavior are empiricaly identified: addictive, aggressive, delinquent behavior, violations of rules and rules. Characteristic features of the above-mentioned forms are trends in alcohol and drug use, uncontrolled manifestations of aggression, violence, violation of generally accepted norms and rules that function in society, which in the future may lead to the commission of unlawful acts by adolescents. The article presents the results of the implementation of a comprehensive program of correction of adolescent deviant behavior.
\end{abstract}

Keywords: parenting style, teenage addictiveness, delinquent behavior, norm violation, deviant behavior.

\section{Introduction}

The problem of deviant behavior in modern Ukrainian society is very urgent. This is one of the most important scientific problems of psychology, pedagogy, sociology of deviant behavior, psychology of personality and more. This type of behavior is a consequence of social, economic and cultural factors. This is due to the fact that during this period there is a process of body restructuring, the transition from childhood to adulthood, maturity, which touches on all aspects of adolescence. Deviation from adolescence has become a particularly urgent problem in recent decades. There is a steady increase in the number of adolescents with deviant behavior, characterized by 
"SOCIALIZATION \& HUMAN DEVELOPMENT" INTERNATIONAL JOURNAL

committing destructive, conflict, asocial, aggressive actions.

The purpose of the presented study is to examine the relationship between type of family education and adolescent deviant behavior.

\section{Theoretical background}

A review of scientific sources showed that the focus of attention of scientists (I. Bech, N. Bulatevich, L. Zhuravleva, O. Zaporozhets, N. Kalina, A. Mambetova, Y. Ryabchich, O. Vlasova, E. Prokopovych, L. Volnova , E. Zmanovskaya and others) remains central to the impact of family on adolescent behavior. An increase in the number of adolescents with deviant behavior is associated with a worsening social situation, which has led to an increase in families living in difficult or unsatisfactory conditions, an increase in families with conflicting and asocial parenting styles, an increase in the number of families transitioning to development and development. the child to other institutions of socialization.

One of the most common problems among today's youth is the rise in the number of offenses, the increase in violence and addictive behavior among adolescents. It is adolescents who find themselves in a difficult situation due to the lack of their own formed system of stable moral convictions, value orientations, which prevents them from reacting normally to events occurring in the environment.

Deviance (from the Latin word deviatio - deviation) means the actions and actions of people who contradict norms or certain patterns and standards of behavior. The essence of deviant behavior lies in the failure to meet the requirements of social norms, in the choice of another variant of behavior, different from the one adopted in a certain situation, which leads to disruption of the interaction of personality and society.

In psychology, deviant behavior is a deviation from the norms of interpersonal relationships adopted in a particular society over a particular historical period. Negative deviations in human behavior are characterized by the fact that the individual does not acquire a positive experience, is not able to adapt to the norms of behavior adopted in society. Knowledge of the necessary social norms by a person and at the same time their non-compliance testifies to the violation of the socialization process. It is characterized by an imbalance of the processes of the psyche, the inability to adapt to changes in the environment.

OV Zmanovskaya distinguishes the following characteristic features of deviant behavior:

1) repeated, continuous violations of the most important norms and values for a particular society;

2) behavior is conditioned by the general orientation of the individual, not by a crisis, non-standard situation;

3) the behavior is accompanied by various manifestations of social maladaptation, causes negative evaluation by other people;

4) the behavior results in causing real harm to the individual or others (Zmanovskaya, 2003).

The limits of behavior violations are difficult to determine. After all, the transformations that take place in society cause changes in social norms. Therefore, at the social level, behavior with deviations is a form of interaction between society and the individual; it is the persistent behavior of a person who does not conform to social norms, harms the society or the individual 
himself and is accompanied by his social maladaptation. At the personal level, such behavior is a social position, the basis of which is the desire for a deviant style and lifestyle. In the future, this leads to conflict with the social environment, selfdestruction, loss of social contacts and further social maladaptation.

- In general, the psychological manifestations of deviant personality behavior include the following:

- $\quad$ spiritual problems (loss of meaning of life, appearance of inner emptiness);

- deformation of the valuemotivational sphere (characterized by unformed or weakening of moral values, frustration, experiencing internal conflicts);

- emotional problems (eg anxiety or depression, dominance of negative emotions, alexithymia (difficulty in understanding one's own emotions, inability to express them in words), emotional coarsening;

- cognitive distortions (stereotypical, rigid thinking, inadequate attitudes, prejudices);

- negative life experience (presence of mental trauma, experience of violence, negative habits (Azarova, 2009).

- Features of manifestation of deviant behavior in adolescents are found in:

- resisting requests, demands, tips;

- conscious unwillingness to act morally;

- non-motivated, unjustified resistance;

- opposing requests, tips;

- unwillingness, inability to understand oneself;

- ignoring obstacles to selfaffirmation.
- The process of formation and further development of deviant behavior consists of the following stages:

1) the first stage (situational). At this stage, only some symptoms of deviant behavior are manifested, such as non-compliance with certain social requirements, disobedience;

2 ) in the second stage (persistent violations) there is a non-observance and persistent violation of moral and social and norms, characteristic for the given society, possible manifestations of delinquent behavior, which further leads to offenses;

3) the third stage is characterized by the accumulation of the experience of committing criminal acts and approaching them to the criminal ones (theft, violence). The "crisis of identification" (contradictions and misconceptions about oneself and the thoughts of others), which often arises, often causes acute intrapersonal conflict. As a result, the individual begins to perceive their behavior as normal;

4) the fourth stage of deviance is characterized by repeated manifestations of persistent, socially dangerous behavior, joining groups characterized by asocial and antisocial behavior;

5) in the last, destructive stage, a person, especially dangerous deviant behavior, is observed in humans. Characteristic are serious social deviations, separated by the constant alienation of the individual from the social environment and inherent norms and values (Mendelevich, 2005).

The general scientific approach 
"SOCIALIZATION \& HUMAN DEVELOPMENT" INTERNATIONAL JOURNAL

to the classification of behavioral disorders distinguishes the following types and characteristics of deviations:

- "by nature: mental, physical, social (cultural), economic disorders, etc .;

- Degree of deviance: primary (any form of abusive behavior) and secondary (arising from the conscious or unconscious desire of the deviant to act in accordance with the "label" that others have labeled their behavior that took place earlier);

- on the scale of deviance: mass (such as alcoholism), group (behavior of sports fans or music fans), individual or isolated (narcissism, train disturbance kleptomania, etc.);

- by subject of deviance: rejection of individuals (alcoholic woman, suicide), official structures, informal and conditional social groups (anonymous alcoholics, fans, informal, etc.);

- on the duration of deviations: temporary (episodic, for example, influenced by a group) and long (constant);

- on the dynamics of deviance: stable when only one type of asocial behavior (drug addiction, dromomania, etc.) is manifested; unstable when there is a tendency to manifest different types of deviant behavior (alcoholism with aggression towards others, etc.);

- by type of violation and significance of consequences: negative deviations socially disapproved, potentially destructively dangerous for the development of society and the individual (drug addiction, suicide, murder, etc.); positive deviations are socially approved, that is, promoting progress, social development, and personal growth (nonstandardism and progressiveness in political or economic activity);

- in the focus on themselves and others: expansive - invasion of the spheres of life and activity of others, the implementation of various forms of physical, mental and sexual abuse against them; non-expansive - the individual's behavior does not affect the interests of others, but harms themselves (eg, anorexia nervosa); selfish - aimed at pleasure or personal pursuit (sexual deviance, substance abuse); altruistic - directed at the interests of others, often combined with a tendency to self-sacrifice (suicidal behavior of a person committed for the sake of loved ones or the deity he worships, or "for the sake of all mankind");

- on the level of awareness and critical behavior: conscious deviations, when a person realizes that his actions are contrary to certain norms, may experience negative emotions about this, wishes to change his behavior; unconscious deviations are usually inherent in people with mental disorders who are convinced that their behavior is adequate;

- in terms of the structure of deviations: structured (organized) is a group form of behavior within which the roles of all its participants (sectarianism) are clearly distributed; unstructured deviations are characterized by the absence of hierarchical relationships, the regulation of actions "(Volnova, 2009).

Psychological approach to the issue of classification of deviance is based on the selection of socio-psychological differences in types of behavior of a person (Zmanovskaya, 2010).

The overall structure clearly identifies a group of causes that determine the occurrence of deviant behavior in adolescents: socioeconomic, psychological - pedagogical, and medical - biological (Koshova, 2009). 
"SOCIALIZATION \& HUMAN DEVELOPMENT" INTERNATIONAL JOURNAL

One of the dominant factors that influence the emergence and further development of deviant behavior in adolescence is the family environment and all the processes and phenomena that develop in it. The family is the starting point for the formation and development of the individual, so it should maximize the adaptation of the individual who is in it to the conditions of social life, as well as prepare the ground for adoption by the teenager of social norms (Zubkov, 2011).

The formation of deviance in adolescence is based on all of the above factors, which interact to cause the emergence and further development of deviant behavior in adolescence.

The family is the most important primary environment that has a dominant influence on the formation and development of the individual. It is a process of assimilation of social norms and values, the need for love, security, attention, belonging, the experience of interpersonal relationships is accumulated. The family performs functions such as upbringing, housing, material and economic, primary social control, communicative, emotional, regulatory.

If the needs of the teenager are not met and the family functions are not fulfilled, this can lead to extremely negative consequences. There is a disruption of the process of socialization, and there may be various abnormalities and disorders related to physical and mental development. It is under these conditions that the deviant behavior is formed and further developed. The most characteristic of these types of families, such as families at risk, in this category are socially disadvantaged families in need of social assistance and support, such as lowincome, multi-child, disabled children, incomplete; Asocial families, this type of families is characterized by heavy interaction, their condition requires fundamental changes, in such families, the adult family environment leads an immoral, unlawful lifestyle; disadvantaged families, such families are characterized by disturbed structure, lack or blurring of internal boundaries, they undergo a process of depreciation or neglect of basic family functions, defects in education that cause disturbance of the psychological climate in the family. Each of the above categories deliberately causes the formation of different types of abnormalities in children. As a result, the child does not know how, or is not able to behave reasonably in society, characterized by the lack of love, understanding, support from the parents.

In order to determine adolescents' predisposition to deviant behavior, to measure predisposition to various forms of deviance, to identify errors in the process of family education and types of family education that may cause deviant behavior in adolescents, we conducted a study.

\section{Methodology}

To investigate the selected problem, we used standardized questionnaires:

Questionnaire for determining predisposition to deviant behavior (OM Orel). The main purpose of the technique is to diagnose the predisposition to deviant behavior, to measure the predisposition of adolescents to perform various forms of deviance. The technique involves taking into account the setting of the socially desirable responses of the subjects. In this technique, the scales are divided into substantive and official. Content scales are aimed at measuring the psychological content of a complex of related forms of deviant behavior (social and personal attitudes that determine these behavioral 
manifestations). The service scale aims to measure the propensity of the respondent to provide socially desirable answers, a general assessment of the reliability of the answers received (Nabiullina, 2008).

Questionnaire for parents "Types of parenting", VB Shapar. Using this questionnaire allows you to find out the type of family upbringing observed in the family environment of counting. When accentuating several types of family upbringing, it can be concluded that there is a contradictory upbringing in the family, which in turn may be the cause of the emergence and development of deviance in adolescents (Bondarchuk, 2001).

Questionnaire for Parents "Analysis of Family Relationships"

(ACS)

(Eidemiller E.G., Yustitskis V.V.). The use of this technique is conditioned by the possibility of detection by the questionnaire of errors in the process of family education and types of family education that can cause deviant behavior in adolescents. This technique is aimed at identifying the type of parental education and finding errors in it. It helps to diagnose dysfunction in the system of mutual influence of family members, disorders in the structural and role aspect of family life and in the mechanism of its integration (Panok, 2001).

The study was conducted during 2019 at the Ukrainian Physics and Mathematics Lyceum of Taras Shevchenko National University of Kyiv and was based on a survey of 60 families, namely 60 adolescents aged 14-16 years and 60 parents who are parents or guardians of adolescents.

\section{Results}

The results of the study can be divided into two directions. The first is aimed at diagnosing adolescents, namely their propensity for deviant behavior and their relationship to the family environment. The second is aimed at the diagnosis of parents, the types of family upbringing and the cause of deviations in the educational process.

The study found that adolescents are prone to such forms of deviance as violations of rules and regulations (57.3 b), addictive behavior $(58.5 \mathrm{~b})$, aggressive behavior (54.3 b), volitional control (55, 6 b), delinquent behavior (53.4 b. Grades above 50 points indicate abnormality) (see Figure 1). The results of the ADOR questionnaire indicate a lack of positive interest on the part of parents and the family environment in adolescents, the passive role of parents in the upbringing of children, the manifestation of hostile and aggressive position on the part of parents.

In the study of types of family upbringing it was found that the dominant types are (according to the results of the questionnaire "Types of upbringing of children", VB Shapar): hypoopic (6.1), neglect (5.9), Cinderella (5.4), contradictory upbringing (5.1). According to the EIA (Eidemiller E.G., Yustitskis V.V.), dominant types of education such as hypoprotection and emotional rejection were identified. The main causes of disturbances in the educational process are the underdeveloped parental feelings (6.33), the projection of the adolescent's own undesirable qualities (3.17), parental insecurity (2.17).

Analyzing the results of VB Shapar's questionnaire "Types of child-rearing", a significant correlation was found between the presence of deviant behavior and such types of family education as hypoopic (0.61), homelessness (0.58), "idol of family" ( 0.50), Cinderella $(0.51)$, 
"SOCIALIZATION \& HUMAN DEVELOPMENT" INTERNATIONAL JOURNAL

Hedgehog Mittens (0.54), Controversial Education (0.52), Hyperopic (0.56).

In the analysis of the results of questionnaires (ACS) (EG Eydemiller, VV Yustitskis) a direct correlation between deviant behavior of adolescents and hyperprotection (0.62), hypoprotection $(0.51)$, excess of requirements-prohibitions $(0.50)$.

In order to correct the deviant behavior of adolescents, a training program for adolescents aged 14-17 years was developed, which is designed for 10 classes. The purpose of the program - to promote the formation of self-control skills, the achievement of positive changes in behavior, the correction of manifestations of deviant behavior, the formation of skills of reflection. Legal work with parents of teenagers was also conducted.

The objectives of the program were: diagnosis of adolescents' predisposition to deviant behavior; facilitating the creation of a personal scale of deviant behavior that will allow you to get an idea of the optimal response styles in different situations; assistance in the formation of self-control skills, control of the emotional sphere; formation of self-examination skills, conscious correction of one's behavior.

Forms and methods of work were chosen information, testing, reassessment, "brainstorming", psychological games and exercises, role-playing situations, training games, projective drawing techniques.

Exercises "Dating", "Who I am", "Group interview", "I'm pleased when ..." intended to familiarize participants with the conditions of work of the training group and to create rules of work of the group, to create a positive atmosphere, to create rules of work in the group, to acquaint the participants with the diagnosis of addiction.
Cheers Compliment, Greetings and Mood, Self-Test, Self-Exercise, Brainstorming What Hinders Me? aimed at establishing trust and understanding between members of the group, developing self-examination, and forming a culture of self-reflection.

The analysis of the causes of aggression in our lives, the urge to reflect on the expediency of aggressive behavior were conducted through the diagnosis of aggression, exercises "Communication with an aggressive interlocutor", "I do not tolerate ...", "Cardboard lock", "Auction", "Wishes on ».

Getting acquainted with your own misdeeds and petty guilt, playing a problematic situation, finding a solution, removing emotional and physical tension were performed using the exercises "Conflict Chair", "Figure deviation of norms of behavior", "Fire-ice" and information message on the topic: "Deviant and delinquent behavior of adolescents and their consequences".

The informational message "Life Values", exercise "Life Values", game "Account for ten", exercise "Suitcase on the road", exercise "Give a smile to a friend" were aimed at creating conditions for adolescents to appeal to their own value and sense sphere.

Formation of skills of adequate evaluation of others, opening of internal problems for further work with them, release of negative emotions, assessment of internal state of participants was carried out by means of exercises "Image of emotions", "Feedback", "Create personal scale of truancy", "Create personal a healthy lifestyle scale. "

The development of constructive means of controlling one's behavior, awareness of oneself from the position of 
"SOCIALIZATION \& HUMAN DEVELOPMENT" INTERNATIONAL JOURNAL

leader and formation of cooperation skills, developing patience for the shortcomings of others were realized through exercises "Confusion", "Silent cry", "King" and informational message on the topic: "Alternative to violation" .

Exercises "Beginner", "Love Anger", "Social Masks", "Icons", "Compote" aimed to identify the causes of violations of the norms of behavior, the formation of the ability to find positive behavioral reactions and experiences, play roles and learn different behavior strategies in conflict situations, giving the opportunity to see conflict situations from different sides.

Playing conflict situations, finding a constructive way out of them, enhancing knowledge on finding a way out of problematic situations, raising self-esteem, creating a positive mood were implemented through exercises "Mirror", "Carpet of Light", "Exit!", "Self-praise" and information message: "Managing your emotions".

Exercises "Sculpture", "I want to tell my colleague", "I am in the past. I do now. I'm in the Future", "Journey to the Future "were used to summarize, receive training performance information from training participants, receive feedback from training participants, reflections, re-diagnose addiction addiction, complete group interaction.

An important factor in correcting deviant behavior in adolescence is information work with parents of adolescents. This part of the correction included information and legal work and touched upon the following issues: informing parents about the concept of deviant behavior, its manifestations and consequences; informing on the responsibility (including criminal) for committing delinquent actions; research on the features of family upbringing in these families, information on the influence of this factor on the development of deviant behavior in adolescents.

After the training program, the adolescents' predisposition to deviant behavior was re-diagnosed and the results obtained were compared, which showed a decrease in the inclination level from an average of 54.76 before the program to 46.2 after the training program (see Figure 2) and for each of the indicators: rules and regulations (46.2), addictive behavior (51.2), self-destructive behavior (46.8), aggressive behavior (44.1), volitional control (45.4), delinquent behavior (43.4) (see figure) 1). 
"SOCIALIZATION \& HUMAN DEVELOPMENT" INTERNATIONAL JOURNAL

Fig. 1. Comparison of results of predisposition to deviant behavior in adolescents before and after training

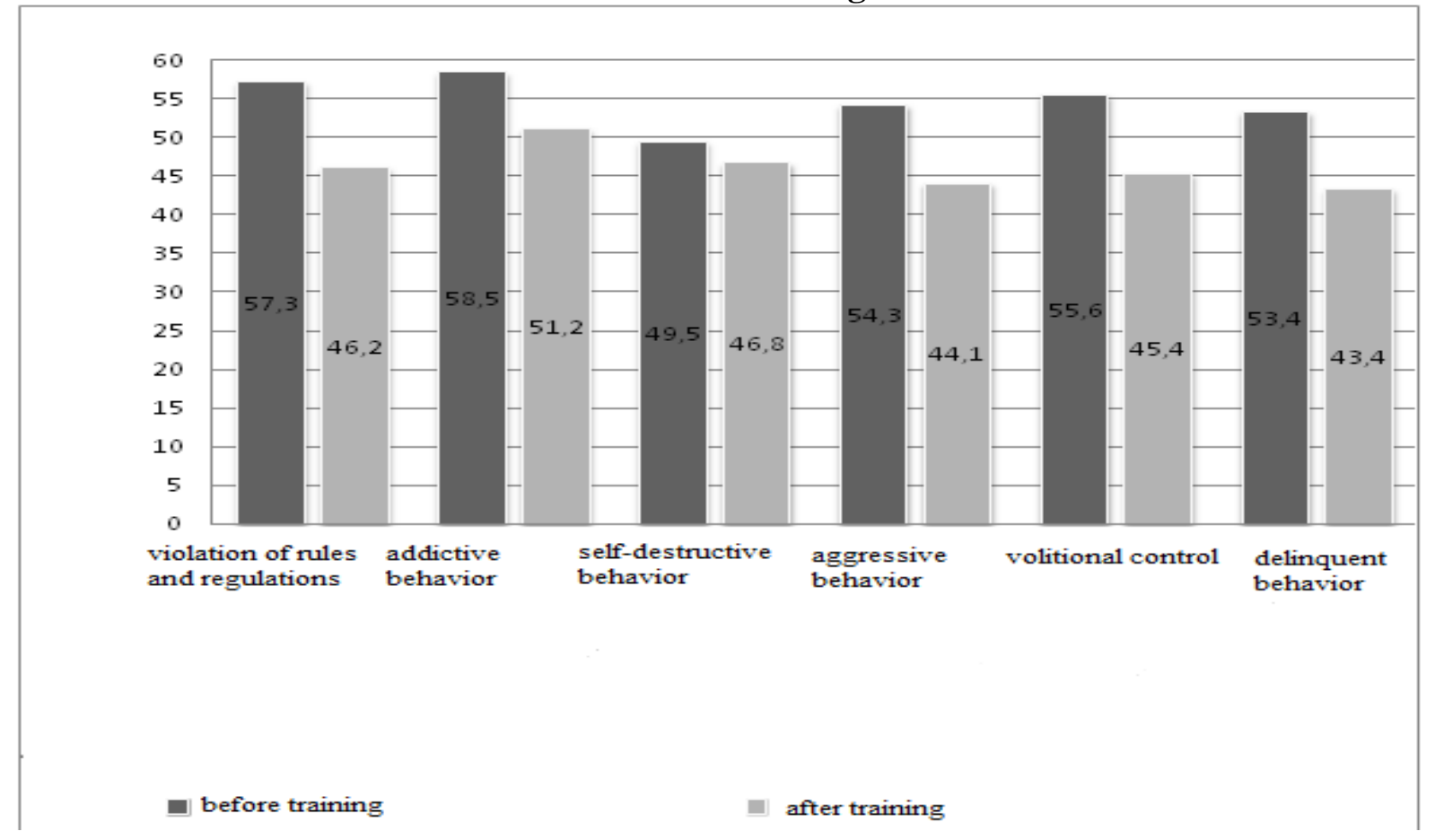

Fig. 2. Comparison of the average overall propensity for deviant behavior in adolescents before and after training

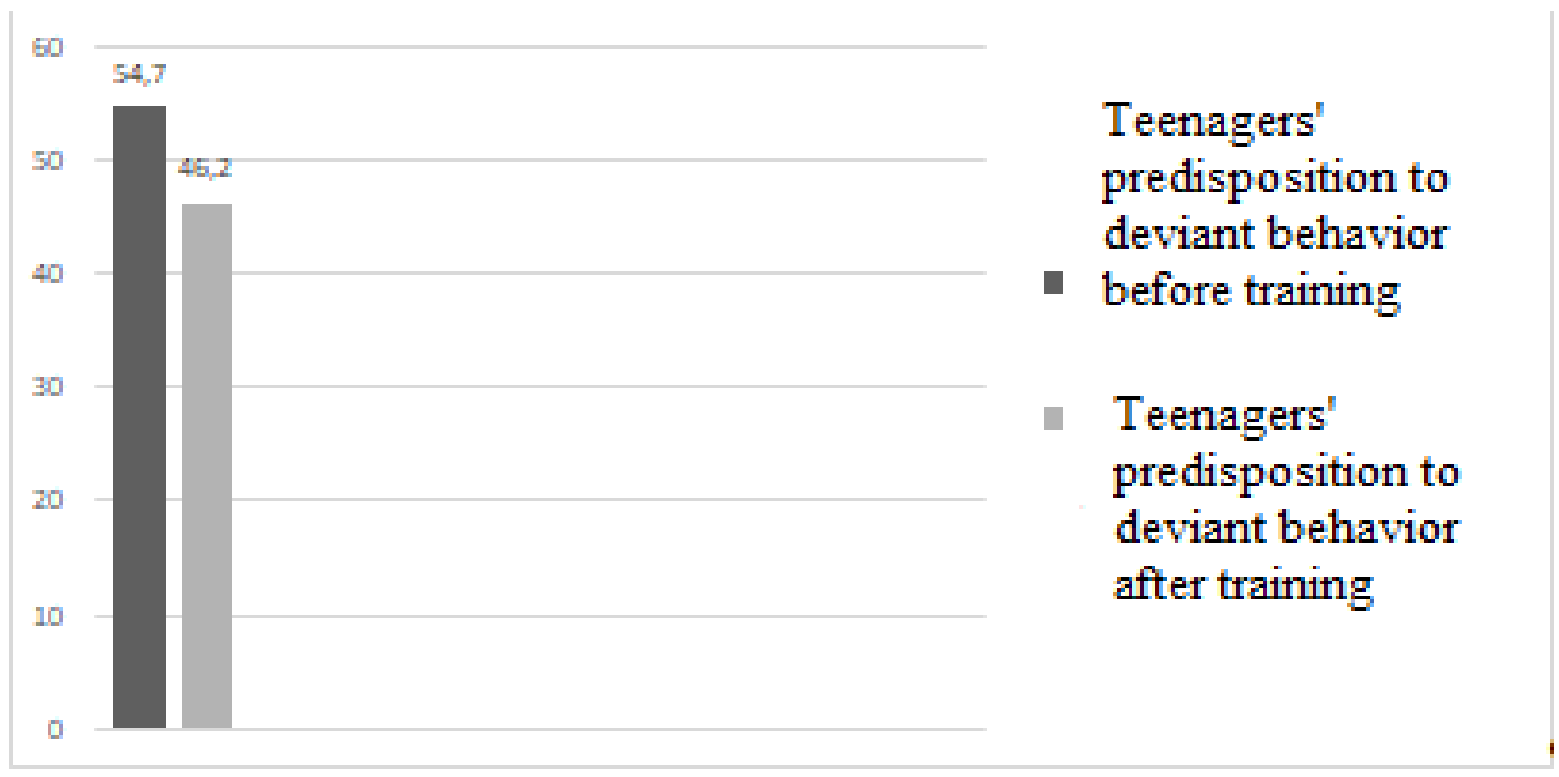

Comparing the results, we see a decrease in the propensity to implement various forms of deviant behavior in adolescents, which indicates the effectiveness of this training program and the relationship between the type of family education and deviant behavior of was conducted with adolescents. adolescents.

\section{Discussion}

The process of conducting our research was divided into two directions:

1. Conduct an empirical study on the predisposition to deviant behavior and their relationship to the family environment that 
"SOCIALIZATION \& HUMAN DEVELOPMENT" INTERNATIONAL JOURNAL

2. Conducting an empirical study with adolescent parents, whose main purpose was to identify types of family education and to identify errors in the process of family education.

In such a fundamental and comprehensive approach, in our view, the uniqueness of this study is in comparison with the work of other researchers (Zhuravl'ova, Kolomiets', 2013; Volnov, 2009).

The study was conducted in several stages. At the organizational stage, theoretical information concerning the problem of forming deviant behavior was elaborated. In the second stage, empirical research was conducted using standardized techniques. The next stage was the processing and interpretation of the results. Based on the results obtained, a training program was developed to correct deviant behavior in adolescents, which includes a comprehensive approach (work with adolescents and their parents). After the training, a retest was conducted regarding adolescents' predisposition to deviant behavior to obtain results regarding the effectiveness of the training program.

In addition, there are limitations to the results obtained. Yes, the study hypothesis was tested only on adolescents. However, it is also promising to study the more distant effects of parental parental influence - how it may manifest in adulthood, in relation to their children taken from their parental family, and in parent-child relationships already in the young family, and so on. Although similar studies already exist (Vlasova, 2019; Zhuravl'ova, Kolomiets', 2013; Zmanovskaya, 2010; Volnova, 2009), we have focused on the influence of parenting styles on adolescent deviant behavior formation and the development of a psychological program for normalizing adolescent behavior. This study opens up the potential for further scientific research and highlights the relevance of the chosen direction of scientific research.

\section{Conclusion}

As a result of a study of the influence of the family on the formation of deviant behavior in adolescents, we have established the following patterns. Teenagers with deviant behavior are characterized by resistance to the demands and demands of society, conscious unwillingness to behave (morally), resisting requests and advice, unwillingness, inability to understand others, ignoring obstacles to selfaffirmation, conscious, deliberate violations of society's rules and regulations.

An important factor in the emergence and development of deviant behavior is the family environment and the processes that take place in it. If there is a disharmonious type of upbringing in the family, destructive types of parenting, the risk of deviant behavior in their children is significantly increased. If the living needs of the family environment are not met, socialization is impaired, and various pathologies and abnormalities related to the physical and mental development of the adolescent may occur. It is under these conditions that deviant behavior is formed and developed.

The study found that adolescents' predisposition to various forms of deviant behavior has a direct correlation with such types of family upbringing as hypoopic, neglect and hyperopic, contradictory upbringing, emotional rejection, and cruel rejection.

Therefore, summarizing the results, it should be noted that the most common 
"SOCIALIZATION \& HUMAN DEVELOPMENT" INTERNATIONAL JOURNAL

forms of deviation are addictive, aggressive, delinquent behavior, violations of rules and regulations. Characteristic features of the abovementioned forms are trends in alcohol and drug use, uncontrolled manifestations of aggression, violence, violation of generally accepted norms and rules that function in society, which in the future may lead to the commission of unlawful acts by adolescents. After applying the correction program, a decrease in adolescents' predisposition to deviant behavior was recorded. This encourages us to continue our study of selected issues and to create and improve correctional programs, which opens the prospects for our further research.

Gratitude. The study did not receive a grant from any financial agency in the public, advertising or non-profit sectors.

\section{References}

Azarova L.A. (2009). Psihologiya deviantnogo povedeniya [Psychology of deviant behaviour]. Minsk. GIUST BGU [in Russian].

Bondarchuk O. I. (2001). Psykholohiia simi: Kurs lektsii [Family Psychology: A Lecture Course]. K.: MAUP [in Ukrainian].

Bondarchuk O. I. Psykholohiia simi: Kurs lektsii. - K.: MAUP, 2001

Bratchenko S.L. (1997). Diagnostika lichnostno-razvivajushhegosja potenciala. Metodicheskoe posobie dlja shkol'nyh psihologov [Diagnostics of personalitydeveloping potential. Methodical manual for school psychologists.]. Pskov. S. 34 -56. [in Russian].

Bulatevich N., Mambetova A. (2018). Psychological peculiarities of parenthood apprehensions of Ukrainians and Crimean Tartars. International Journal of Education \& Development, 1, 13 - 24.

Duhnovskij S.V. (2009). Diagnostika mezhlichnostnyh

Psihologicheskij

[Diagnostics otnoshenij. relationships. praktikum

Practical Training ] / Duhnovskij S.V. - SPb.: Rech'. 141. [in Russian].

Eliseev O.P. (2001). Praktikum po psihologii lichnosti [Practical work on personality psychology ]. $\mathrm{SPb}$.: Piter. 560. [in Russian].

Koshova, Inna Viktorivna. Psykholohiia deviantnoi povedinky : navch. posib. / Koshova I. V., Kresan O. D.; Nizhyn. derzh un-t im. M. Hoholia. - Nizhyn : Vyd-vo NDU im. M. Hoholia, 2009.

McLaughlin K. A., King K. (2015). Developmental trajectories of anxiety and depression in early adolescence. J. Abnorm. Child Psychol. 43 311-323. 10.1007/s10802-014-9898-1

Mendelevich V. D. (2005). Psikhologiya deviantnogo povedeniya : uchebn. posobiye [Psychology of deviant behavior: textbook]. SPb. Rech [in Russian].

Moilanen K. L., Rasmussen K. E., PadillaWalker L. M. (2015). Bidirectional associations between self-regulation and parenting styles in early adolescence. J. Res. Adolesc. 25 246-262. 10.1111/jora.12125

Nabiullina V.R. (2008). Tipy semeynogo vospitaniya i ikh raznovidnosti. Dopolnitelnoye obrazovaniye i vospitaniye [Types of family education and their varieties. Further 
education and upbringing]. №11. 13s. [in Russian].

Nabiullina, V.R. Tipyi semeynogo

vospitaniya $i$ ih raznovidnosti //

Dopolnitelnoe obrazovanie i

vospitanie [Tekst] / V.R. Nabiullina. - 2008. - \#11. - 13s.

Panok V. H., Tytarenko T. M., \& Chepelieva N. V. (2001). Osnovy praktychnoi psykholohii

[Fundamentals of practical psychology]. K.: Lybid [in Ukrainian].

Panok V. H., Tytarenko T. M., Chepelieva

N. V. Osnovy praktychnoi

psykholohii. - K.: Lybid, 2001

Prokopovych Y. (2017). Psykholohichna kharakterystyka mikrosotsialnykh chynnykiv internet-zalezhnoi povedinky pidlitkiv [Psychological characteristics of microsocial factors of adolescent Internetdependent behavior]. Visnyk Kyivskoho natsionalnoho universytetu imeni Tarasa Shevchenka. Psykholohiia Psychology, 2, 116 - 120 [in Ukrainian].

Riabchych I. (2018). Psykholohiia obdarovanosti [Psychology of giftedness]. Kyiv: «TsP «KOMPRYNT» [in Ukrainian].

Van der Graaff J., Carlo G., Crocetti E., Koot H. M., Branje S. (2018). Prosocial behavior in adolescence: gender differences in development and links with empathy. J. Youth Adolesc. 47 1086-1099.

10.1007/s10964-017-0786-1

Van Lissa C. J., Hawk S. T., Koot H. M., Branje S., Meeus W. H. J. (2017). The cost of empathy: parentadolescent conflict predicts emotion dysregulation for highly empathic youth. Dev. Psychol.53 1722-1737. 10.1037/dev0000361

Vlasova O.I. (2019). Influence of internet dependency on youth selfactualization. Socialization \& Human Development: International Scientific Journal, 1, 1, 5-12.

Volnova L.M. (2009). Profilaktyka deviantnoi povedinky pidlitkiv : navch.-metod. posib. do spetskursu sots.-ped. tsyklu «Profilaktyka deviant. povedinky pidlitkiv» $\mathrm{K}$. Vyd-vo NPU im. M. P. Drahomanova [in Ukrainian].

Zhuravl'ova L.P., Kolomiec' T.V. (2013). Empatijna determinacija kognitivnih stiliv mizhosobistisnoji vzaemodiji $u$ junac'komu vici [The empathic determination of cognitive stiles of inter-personal interaction at the juvenile age ] // Problemi zagal'noji ta pedagogichnoji psihologiï: $\mathrm{Zb}$. nauk. prac' Institutu psihologiji im. G.S. Kostjuka APN Ukrajini, [za red. S. D. Maksimenka]. - K. T. XV, ch. 1. - S. 104 - 112. [in Russian].

Zmanovskaya E.V.

(2003). Deviantologiya. Psihologiya otklonyayushego povedeniya [Deviantology. Psychology of deviant behaviour]. M. Izdatelskij centr «Akademiya» [in Russian].

Zmanovskaya E.V. (2010). Deviantnoe povedenie lichnosti i gruppy [The deviant behavior of the individual and the group]. SPb. : Piter [in Russian].

Zubkov V. I. Deviantnost molodYozhi kak rezultat ee neadekvatnoy sotsializatsii / V. I. Zubkov // Sotsialno-gumanitarnyie znaniya. 2011. 